\title{
Effective control of ammonia loss in the manure collection pit of caged poultry layer system by coir pith application
}

\author{
M.PRASANTHRAJAN
}

\begin{abstract}
Poultry ownership provides a great opportunity for improved self resilience small scale agricultural sustainability through egg and meat production. The main issue of caged system poultry industry is managing the poultry droppings that build up in the manure collection pit beneath the cage. If not managed properly this waste material can create odour and attracts flies. Composted poultry droppings, on the other hand, can be an excellent resource for improving the soil health and fertility. During the storage of poultry droppings in the manure collection pit, huge quantity of nitrogen is lost in the form of ammonia. When composting a low $\mathrm{C} / \mathrm{N}$ ratio material such as poultry droppings, it may be beneficial to add carbon instead of adding nitrogen which would boost the nitrogen immobilization and reduce volatilization. Adding a dry material with high carbon content in the manure collection pit periodically would reduce the moisture content of poultry droppings and temporarily immobilize the $\mathrm{NH}_{4}^{+}$by arresting the microbial activity for a short while. Keeping in view the present study was undertaken by applying dry coir pith into caged pit manure collection system to minimize the ammonia volatilization. Periodical application of coir pith into manure collection pit maintained the in-house ammonia concentration below $25 \mathrm{ppm}$ which was $34 \mathrm{ppm}$ at the beginning. After a period of three months, poultry droppings along with added coir pith were scraped out and allowed for composting and this compost found to be rich in $\mathrm{N}(2.08 \%)$ with optimum $\mathrm{C} / \mathrm{N}$ ratio 13.54:1.
\end{abstract}

KEY WORDS : Caged pit system, Poultry waste, Coir pith, Ammonia conservation

HOW TO CITE THIS PAPER : Prasanthrajan, M. (2016).Effective control of ammonia loss in the manure collection pit of caged poultry layer system by coir pith application. Res. J. Animal Hus. \& Dairy Sci., 7(2) : 80-83 : DOI: 10.15740/HAS/RJAHDS/7.2/80-83.

\section{AUTHOR FOR CORRESPONDENCE}

M. Prasanthrajan, Forest College and Research Institute (T.N.A.U.), METTUPALAYAM (T.N.) INDIA

Email : prasanth_phd@yahoo.co.in 